\title{
Epidemiology of Xiphinema americanum and Tomato ringspot virus on Red Raspberry, Rubus idaeus
}

J. N. Pinkerton, J. Kraus, R. R. Martin, and R. P. Schreiner, U.S. Department of Agriculture, Agricultural Research Service, Horticultural Crops Research Laboratory, Corvallis, OR 97330

\begin{abstract}
Pinkerton, J. N., Kraus, J., Martin, R. R., and Schreiner, R. P. 2008. Epidemiology of Xiphinema americanum and Tomato ringspot virus on red raspberry, Rubus idaeus. Plant Dis. 92:364-371.

Population dynamics of Xiphinema americanum and transmission of Tomato ringspot virus (ToRSV) were studied in a red raspberry field in Washington State. Population densities of $X$. americanum were highest in the winter, lowest in the summer, and were correlated with precipitation $\left(R^{2}=0.42\right)$. All nematode stages were present throughout the year. Gravid females were observed only in the spring, indicating one generation per year. The sequence of the coat protein of the ToRSV from this field was similar to those of other raspberry isolates from the Pacific Northwest. Cucumber seedlings were planted in soil collected monthly from the field and were evaluated for nematode transmission of ToRSV by enzyme-linked immunosorbent assay (ELISA). The proportion of assay plants infected with ToRSV was negatively correlated with nematode densities $\left(R^{2}=0.31\right)$. In another study, ToRSV was detected by ELISA in fine roots of raspberry plants 5 months after planting in field soil infested with viruliferous nematodes, in all subterranean portions of plants after 12 months, and in all aerial portions the second year. The rate of spread of ToRSV in a raspberry field was $70 \mathrm{~cm}$ per year. These results suggest that the rate of ToRSV spread is limited by systemic spread of virus in plants when nematode-infested soil is not transported in the field.
\end{abstract}

Additional keywords: dagger nematode, nepovirus, vector

Several nematode species of the Xiphinema americanum group (Nematoda, Longidoridae) are economically significant parasites of plants and vectors of plant nepoviruses. These sibling species (50) are distributed widely in North America $(39,42)$ and have wide host ranges including both annual and perennial plants $(33,42) . X$. americanum is an ectoparasite that feeds at root tips, branching points, and on the sides of young roots (15). Symptoms observed on maple seedlings grown in soil infested with $X$. americanum include stunting, sparse roots, and roots with swellings and dark lesions (15). $X$. americanum reproduces well on red raspberry, Rubus idaeus, but causes little direct damage (30).

The major economic impact of $X$. americanum is that it vectors several nepoviruses: Tobacco ringspot virus (TRSV), Cherry rasp leaf virus, Cherry leaf roll virus, Peach rosette mosaic virus, and Tomato ringspot virus (ToRSV) (6).

Corresponding author: J. N. Pinkerton

E-mail: pinkertj@hort.oregonstate.edu

Accepted for publication 13 June 2007.

doi:10.1094/PDIS-92-3-0364

This article is in the public domain and not copyrightable. It may be freely reprinted with customary crediting of the source. The American Phytopathological Society, 2008.
Virus particles ingested with plant cytoplasm adhere to the cuticular lining of the esophagus and lumen of the stylet $(7,52)$. The specificity of transmission among different nepoviruses and nematode vectors $(9,52)$ is hypothesized to be related to affinity of virus coat protein for specific carbohydrate moieties in glycoproteins lining the wall of the esophagus (9). Upon initiation of feeding, nematodes inject a digestive secretion from the dorsal esophageal gland, purging virus particles from the esophagus into the plant cell, subsequently infecting the plant $(9,52) . X$. americanum can acquire particles of ToRSV within $1 \mathrm{~h}$ of feeding on roots of infected plants, and transfer particles of ToRSV within $1 \mathrm{~h}$ of feeding on healthy plants (46). Viruliferous nematodes stored in soil without host plants can transmit ToRSV for up to 2 years (4). The esophagus and virus are shed with each molt, thus each nematode life stage must feed on a virus-infected host to reacquire the virus (9). Because of this phenomenon, ToRSV can be managed by rotation of crops, such as grasses, that are not hosts for ToRSV, but such rotations will not interrupt the nematode's lifecycle (36).

ToRSV is one of the most economically important virus diseases of red raspberry in North America (44). The cultivars Meeker and Willamette infected with ToRSV show significant decline in vigor, fruit yield, and fruit quality. Chronically infected plants are stunted, produce few primocanes, and often die 4 to 5 years after infection. ToRSV infections first appear as isolated patches in the field that slowly expand to adjacent plants (13). The objectives of our research were to: (i) describe the seasonal population dynamics of $X$. americanum on raspberry, (ii) relate nematode dynamics to transmission of ToRSV, and (iii) describe temporal dynamics of spread of ToRSV within plants and between plants.

\section{MATERIALS AND METHODS}

Nematode population dynamics. This study was conducted in an 8-year-old 'Willamette' red raspberry field in Vancouver, WA (Clark County) on a well-drained Hillsboro silty-loam soil (Fine-silty, mixed, superactive, mesic Ultic Argixerolls). An area of the field with plants symptomatic of ToRSV infection was selected for the study. Plant row orientation was east-west on 3.3-m spacing between rows.

Standard management practices were employed in the plot area (40). In 1999, plots were irrigated with an overhead sprinkler irrigation system on moveable hand lines. Because of inconsistent water availability, an automatic timed drip irrigation system was installed in 2000. Plots were fertilized with $15-15-15$ at $300 \mathrm{~kg} / \mathrm{ha}$ each spring. Alleyways were maintained with a mixture of grass and weeds, and were mowed throughout the growing season. Canes were pruned and trained each winter according to conventional practices.

Environmental data were compiled from local weather stations. Precipitation data were obtained from the National Weather Service (NOAA), Portland, OR, located 10 $\mathrm{km}$ from the plots. Soil temperature data $(20 \mathrm{~cm})$ were obtained from the Oregon State University North Willamette Research and Experiment Station, Aurora, OR.

Three adjacent plots, $18.25 \mathrm{~m}$ long, were established in each of four alternate rows (A, B, C, and D). Twenty soil cores $(30 \mathrm{~cm}$ deep $\times 2 \mathrm{~cm}$ diameter) were collected monthly from the 60 -cm-wide planting row of each plot from January 1999 through December 2002. Nematodes were extracted from a $250-\mathrm{g}$ subsample of soil collected in each plot by a combination of wet sieving followed by 24-h Baermann funnel extraction (27). The remainder of the soil was used in the cucumber bioassay described below. $X$. americanum was pre- 
viously identified on this farm by restriction fragment length polymorphism (RFLP) analysis (50) and confirmed by morphometric analysis in the current study. Individual nematodes were counted by developmental stage, and the number of gravid females was recorded (22). A 100-g subsample of soil from each plot at each sample date was oven-dried at $100^{\circ} \mathrm{C}$ for $48 \mathrm{~h}$ to determine soil moisture content. Soil moisture was expressed as percentage by mass $\left[\left(\mathrm{g} \mathrm{H}_{2} \mathrm{O} /\right.\right.$ total $\left.\left.\mathrm{g}\right) \times 100\right]$.

Detection of ToRSV by cucumber bioassay. The distribution of ToRSV in the experimental area was determined at the start of the population dynamics study. In September 1998, eight raspberry leaves were collected systematically along the row in each plot, and individual leaves were tested for ToRSV infection by enzyme-linked immunosorbent assay (ELISA) procedures (12). Locations of symptomatic plants in rows also were noted.

Bioassay tests were conducted to determine indirectly the population densities of viruliferous nematodes and/or their ability to vector ToRSV. The soil collected monthly from each plot for the 4 years was subdivided after first removing a sample of soil for nematode analysis, and $125 \mathrm{~g}$ of soil was added to each of six $5-\mathrm{cm}$ pots. A cucumber seedling, cv. Straight Eight, was planted in each pot. Pots representing each plot (six pots per plot) were placed on fabric mats on a greenhouse bench, and the mats were irrigated to maintain uniform soil moisture in the pots. Plants were grown for 8 weeks at 18 to $22^{\circ} \mathrm{C}$ with $14 \mathrm{~h}$ of supplementary light $\left(400 \mu \mathrm{mol} \mathrm{m} \mathrm{m}^{-2} \mathrm{~s}^{-1}\right)$ per day.

In 1999 and 2000, a terminal expanded leaf was collected from each cucumber plant and tested for the presence of ToRSV by ELISA. During the last 2 years of the study, in addition to collecting a cucumber leaf, the root system of each plant was collected, washed free of soil, and both samples were tested for ToRSV by ELISA. The proportion of cucumber plants that tested positive for ToRSV was calculated for each plot at each sampling period. The proportion of plants testing positive in each plot and the proportion of plots testing positive were subjected to analysis of variance after arcsine transformation, in order to assess the significance of differences between sampling periods.

Systemic spread of ToRSV. An experiment was conducted adjacent to the nematode dynamics study to follow plant growth and spread of ToRSV in raspberry plants. In April 2001, two 60-m rows of plants with $100 \%$ incidence of ToRSV, based on ELISAs of leaves, were sprayed with glyphosate. The plants were dug up and removed after 2 weeks. Metam sodium was applied by chemigation (962 liters/ha in 20,000 liters of water per ha) in one-half of the experimental area to eliminate nematodes and kill the remaining rasp- berry roots. Two weeks later, a $40 \mathrm{~cm}$ deep $\times 40 \mathrm{~cm}$ wide trench was dug along the centerline of the rows. On 5 May 2001, soil grow bags $(32 \times 32 \times 40 \mathrm{~cm}$; TDI 2 Custom Package Inc., Santa Ana, CA) were filled with either viruliferous nematode-infested or fumigated soil. A 1-yearold, dormant, bare-rooted 'Meeker' red raspberry plant (Sakuma Brothers, Burlington, WA) was planted into each bag, and soil samples were taken for nematode analysis. Bags, 120 containing either infested or fumigated soil, with plants were placed in the trenches at $60-\mathrm{cm}$ spacing, and the trenches were backfilled with the remaining soil. Drip irrigation and trellis systems were installed, and the plants were managed according to standard practices (40), including fertilization with $120 \mathrm{~g}$ of 16-16-16 fertilizer per plant each year and treatment with mefenoxam (Ridomil Gold) at $1 \mathrm{ml}$ per meter of row in the spring to prevent Phytophthora root rot.

Four plant bags were randomly removed from the fumigated and nonfumigated areas at 1- to 3-month intervals for 2 years starting in September 2001. Three $2 \mathrm{~cm}$ diameter $\times 30 \mathrm{~cm}$ deep soil cores were collected from each bag for nematode analysis. Aerial portions of plants were removed and the primocanes, floricanes, and leaves separated. Three samples, consisting of a single leaf or 1-cm-long sections of canes, were collected for ELISA testing for ToRSV, and the remaining tissue was oven-dried at $70^{\circ} \mathrm{C}$ for $48 \mathrm{~h}$. Each bag was soaked in a tank of water to soften the soil, which was then washed from the root system with a pressurized stream of water. Roots that detached from the root system were collected on a screen. The subterranean portion of each plant was separated into fine roots, woody roots $>2$ $\mathrm{mm}$ diameter, crowns, and when present, young primocanes. Eight fine root, four woody root, two crown, and three young primocane subsamples were collected from each plant for ELISA testing. The remaining subterranean tissues were oven-dried for $48 \mathrm{~h}$ and weighed. Plants growing in the fumigated soil were observed for symptoms of ToRSV. Leaf samples were collected from all plants once each year and tested for ToRSV by ELISA.

Systemic spread of ToRSV also was monitored in a greenhouse experiment. Forty-five ToRSV-free 'Meeker' raspberry plants were grafted with shoot tips collected from field-grown 'Willamette' plants infected with ToRSV. These plants were monitored for ToRSV by ELISA testing of terminal leaves of 'Meeker' canes over the following 14 months.

ToRSV spread in a raspberry planting. In 1999, a single raspberry plant with symptoms of ToRSV was observed in a 'Meeker' raspberry field planted near to the field where the population study was conducted. This field had been fumigated with Triform $30 \quad$ (70\% 1,3-dichloro- propene-30\% chloropicrin at 53 liters $\mathrm{ha}^{2}$ ) and planted in spring 1996. Single leaves were collected from the symptomatic plant and from plants at 1-m intervals in a 36-m length of the six rows surrounding the ToRSV focus plant in June 1999. Leaves were tested for ToRSV by ELISA. The grower planted perennial grass in the alleyways and discontinued tillage in this field at the time, as we suggested. This same area of the field was surveyed for ToRSV again in June 2006. Two leaves were collected from plants at 1-m intervals in the same area sampled in 1999 and tested for ToRSV. In 1999 and 2006, 20 soil cores were collected along $20 \mathrm{~m}$ of three adjacent rows centered on the disease focus.

Sequence of the coat protein gene of ToRSV. To characterize the isolate of ToRSV in the field plot (F1), RNA was extracted from symptomatic leaves as described by Spiegel and Martin (43), and used as a template in a reverse transcriptase (RT) reaction using Superscript III (Invitrogen, Carlsbad, CA) and random primers (Invitrogen). This and the following procedures were as specified by the manufacturer. This cDNA was used subsequently in a polymerase chain reaction (PCR) using the coat protein primers ATTCGCGAACGCGTGGAA and CAG CTTGCTTAAGGCTGGA (53) and Platinum Taq polymerase (Invitrogen). The resultant PCR products were cloned in pCR4.1 (Invitrogen) and sequenced by Macrogen (Seoul, Korea). ToRSV coat protein genes were similarly cloned from three other commercial fields in Clark County, WA, and sequenced. Sequences were assembled using Staden software (1996). These and database sequences were analyzed using Pile-up (GCG Version 11.0, Accelrys Inc., San Diego, CA) and ClustalW (47). Percent sequence identities were calculated using ungapped alignments.

\section{RESULTS}

Nematode population dynamics. A Mediterranean-like climate, with cool wet winters and warm dry summers, prevails in raspberry production areas of the Pacific Northwest (PNW) (Fig. 1). During 1999 to 2003, maximum daily soil temperatures $\left(24\right.$ to $26^{\circ} \mathrm{C}$ ) were recorded in late July or August each year, while the minimum temperatures $\left(4\right.$ to $\left.5^{\circ} \mathrm{C}\right)$ were recorded in late December or January (Fig. 1). Precipitation was lowest in August (1 to 18 $\mathrm{mm} / \mathrm{month}$ ) and greatest from November through February (144 to $222 \mathrm{~mm} /$ month). Soil moisture ranged from 8 to $25 \%$ at monthly sampling dates and followed monthly precipitation accumulations (Fig. 1). Irrigation maintained soil moisture at $\geq 12 \%$ through the summer, except in 1999 when irrigation was erratic.

Seasonal dynamics of $X$. americanum populations were similar each year. Popu- 


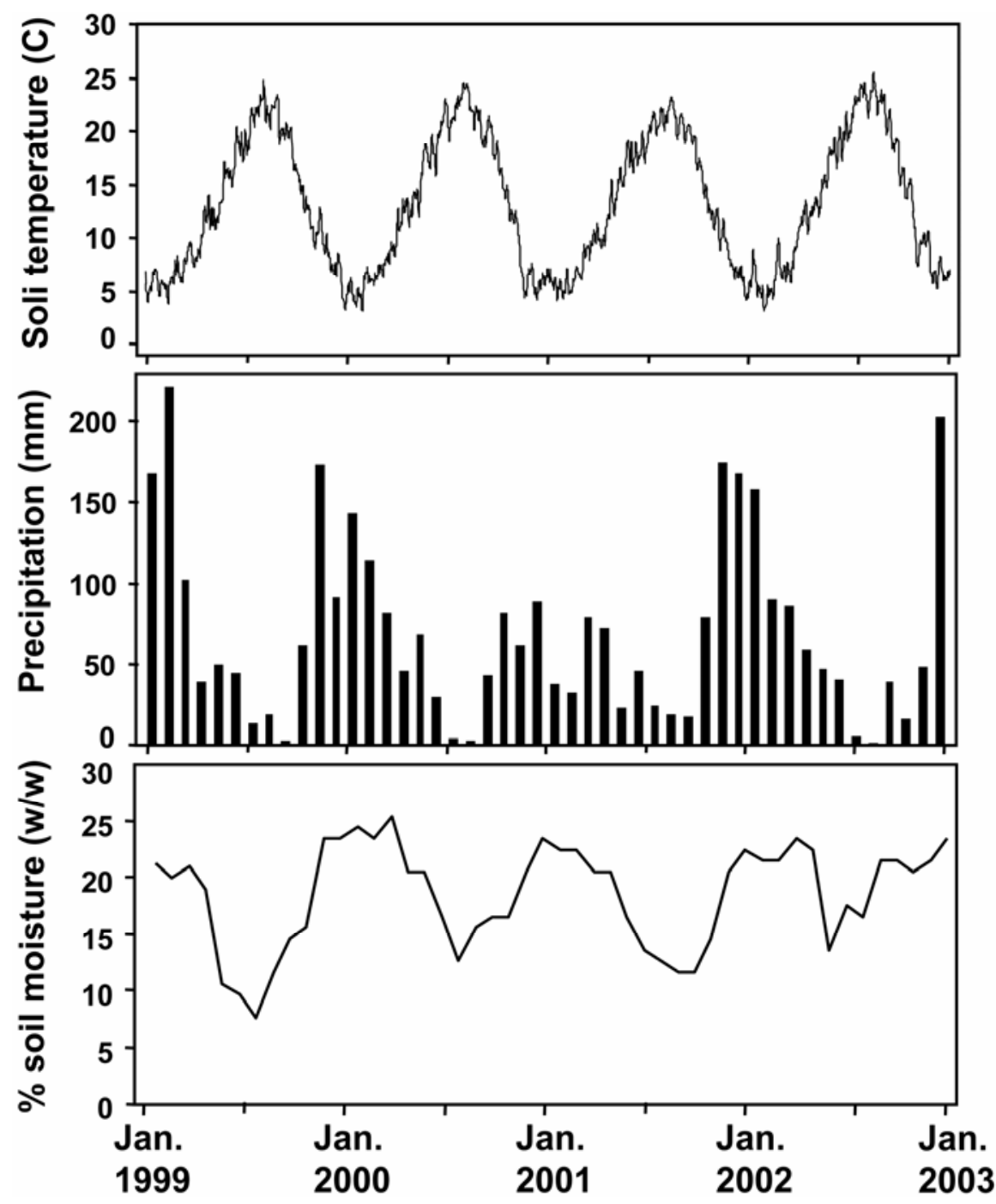

Fig. 1. Precipitation at the National Weather Service, Portland, OR, and 20-cm soil temperature at the Oregon State University North Willamette Research and Experiment Station, Aurora, OR. Soil moisture was based on gravimetric water content of samples collected once each month from the plots.

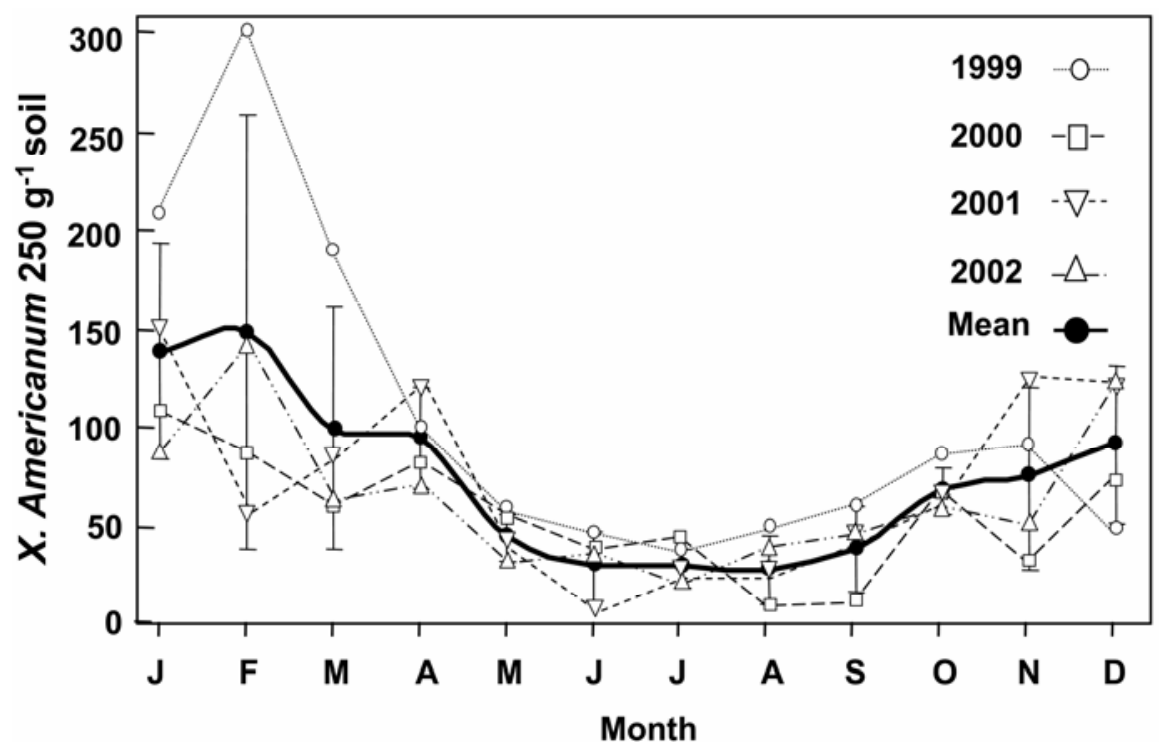

Fig. 2. Mean monthly population densities of Xiphinema americanum in a 'Willamette' red raspberry planting in Vancouver, WA, from 1999 through 2002. Twenty cores $(2 \mathrm{~cm}$ diameter $\times 30 \mathrm{~cm}$ deep) were collected in the plant row within plots. Data are mean population densities from soil collected from 12 plots. Vertical bars represent the standard error. lation densities were greatest in the winter and declined significantly $(P=0.05)$ to the lowest densities in the summer (June through September) (Fig. 2). Except for the winter of 1999, when the greatest nematode population densities were observed, nematode densities recorded for any given month did not differ $(P=0.05)$ among the 4 years. All developmental stages were present throughout the year (Fig. 3). However, the proportion of adults differed $(P=0.03)$ among months. Adults represented $<20 \%$ of the population from November to February, when total nematode population densities were the greatest. Conversely, adults represented $\sim 30 \%$ of the populations from the spring and summer months. Gravid females were observed only from April through June and consisted of less than $20 \%$ of the female population. The proportion of all juvenile stages was greatest in September, but the proportions of all stages did not differ $(P=$ $0.05)$ throughout the year. Nematode population densities were correlated $(P<0.001)$ with monthly precipitation $\left(R^{2}=0.46\right)$, with mean temperature $\left(R^{2}=0.30\right)$, and with soil moisture recorded on the sampling dates $\left(R^{2}=0.18\right)$.

Seasonal detection of ToRSV. Based on visual observation of symptoms and ELISA results from raspberry leaves sampled in fall 1998, prior to the beginning of the experiments, there was a disease gradient in the field with greater severity and incidence of ToRSV in rows A and B than in row $\mathrm{C}$ (data not presented). ToRSV was not detected in leaves collected from row D during 1999 and 2000. However, ToRSV was detected in raspberry leaves collected in plots in all rows during 2001 and 2002, indicating that ToRSV was probably present at a very low frequency in row D during 1999 and 2000.

ToRSV was detected consistently in leaves of cucumber plants assayed during the summer, but inconsistently in leaves of cucumber plants assayed during the winter (data not presented). However, ToRSV was detected in roots of cucumber plants grown throughout the year. Detection of the virus in assay plants tended to be greater from June through October, although differences between months were generally not statistically significant (Table 1). There was a negative correlation $\left(P<0.057, R^{2}=0.31\right)$ between log-transformed nematode population densities and the proportion of plots in which ToRSV was detected in cucumber roots in 2001 and 2002.

Systemic spread of ToRSV. ToRSV was detected in a single fine root sample from one plant on the first sampling date in September 2001, 5 months after planting. Two months later, virus was detected in all the fine and woody root samples and in the young primocanes of two additional plants. From December 2001 through the end of the study, ToRSV was detected in at least one sample of each plant part collected 
from each plant. Plants grown in fumigated soil remained free of ToRSV, based on plant symptoms and ELISA testing of leaf samples.

By December $2001,>42 \%$ of fine root and $75 \%$ of woody root samples tested positive for ToRSV (Fig. 4). In the second growing season, the virus was detected in more than two-thirds of fine and woody root samples, and in March 2003, all root samples tested positive. Approximately one-half of the immature primocanes contained ToRSV in the fall and winter of 2001 to 2002 before they emerged from the soil. ToRSV was detected in most mature primocanes during the second growing season. Shoots and leaves that developed from the original plant in the first year were free of ToRSV, but leaves produced the second season were infected with the virus.

Growth of plants infected with ToRSV was reduced significantly compared with virus-free plants grown in the fumigated soil (Fig. 5). Fine and woody root growth of virus-infected plants was suppressed by the end of the first season, and there was little additional growth in the second season. Conversely, root mass of virus-free plants increased greatly from May through September in 2002. Cane and leaf mass followed the same pattern both years, with little increase in mass of ToRSV-infected plants compared with virus-free plants. Virus-infected plants were not sampled in May 2003, because most of the remaining virus-infected plants died by the 2003 season.

Population densities of $X$. americanum remained low during the 2-year study. Mean population density was $16 \pm 4$ nematodes per $250 \mathrm{~g}$ of nonfumigated soil when the bags were filled. Subsequently, the mean monthly population density (averaged over 13 sampled dates) was $8.7 \pm 5.9$ nematodes per $250 \mathrm{~g}$ of soil. Fumigated soil remained free of $X$. americanum for the 2 years.

ToRSV spread slowly in raspberry plants that were grafted with shoots from ToRSV-infected plants. The frequency of detection of ToRSV by ELISA in newly emerged terminal leaves was linear, increasing by $0.03 \%$ of the plants per month $\left(R^{2}=0.99\right)$ (data not presented). After 14 months, $42 \%$ of the plants were infected systemically.

ToRSV spread in a raspberry planting. ToRSV spread very slowly from the disease focus in the 'Meeker' raspberry field. In 1999, only the plant with symptoms of ToRSV and the two adjacent symptom-free plants tested positive for ToRSV with ELISA. Seven years later, in June 2006, several plants within $2 \mathrm{~m}$ of the focus had died, and ToRSV was detected in leaves collected from all plants up to 5 $\mathrm{m}$ from the initial focus in both directions along the row, but not in the rest of the row. Mean rate of annual spread was 70 $\mathrm{cm}$ per year. ToRSV was not detected in rows adjacent to the disease focus. Population densities of $X$. americanum increased from 2 to 25 nematodes per $250 \mathrm{~g}$ of soil from 1999 to 2006 in the three rows surrounding the disease focus, while density was 11 nematodes per $250 \mathrm{~g}$ in the area that tested positive for ToRSV in 2006.

Genetic characterization of ToRSV isolate. The coat protein sequence of the ToRSV isolate from the study site (GenBank EF370399) was $>99 \%$ identical to the coat protein sequence of ToRSV isolates from three other raspberry fields in southwestern Washington State (EF370399, EF370401, EF370402). A second ToRSV

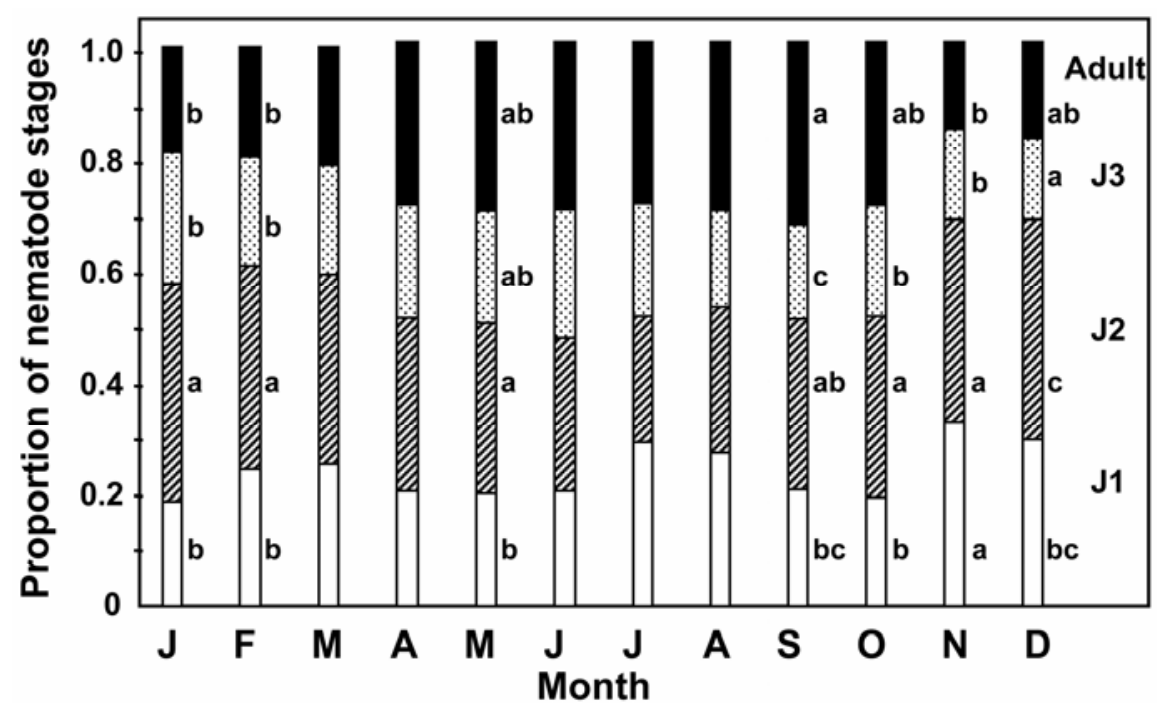

Fig. 3. Mean proportion of adult and the three juvenile stages (J1 to J3) of Xiphinema americanum observed monthly in a 'Willamette' red raspberry field in Vancouver, WA. Soil samples for nematode population analysis were collected from 12 plots each month from 1999 through 2002 . Twenty cores $(2 \mathrm{~cm}$ diameter $\times 30 \mathrm{~cm}$ deep) were collected in the plant row within plots. The proportions of each individual stage in each month with the same letter at the right of each column do not differ $(P=0.05)$ according to Fisher's LSD tests. isolate was identified in one of these fields by its distinctly different coat protein sequence (EF370403) that was 91.8\% identical to the coat protein sequence of the ToRSV isolate from the study site. The coat protein sequence of ToRSV from the study site was 98.2 to $98.8 \%$ identical to two previously sequenced raspberry isolates from northwestern Washington State (AF135413) and British Columbia (D12477).

\section{DISCUSSION}

Relative to most other plant-parasitic nematodes, $X$. americanum and other Xiphinema spp. are K-strategists, having long lifespans and lifecycles with low fecundity rates $(23,24,27)$. Previous studies of population dynamics of $X$. americanum associated with perennial hosts revealed no consistent seasonal fluctuations, and differences between the studies were likely the result of differences in climate and host species, or differences in extraction protocols. Jaffee et al. (27) could not differentiate seasonal patterns in total densities of all stages over a 2-year study in apple and peach orchards in New York and Pennsylvania. In that study, females made up $>50 \%$ of the population throughout the year and were at greatest population densities from late winter to spring. On cottonwood in Iowa, population peaks were observed in early summer and

Table 1. Proportion of cucumber bioassay plants with roots that tested positive for Tomato ringspot virus $(\mathrm{ToRSV})^{\mathrm{w}}$

\begin{tabular}{lll}
\hline Month & $\begin{array}{c}\text { Plants } \\
\text { infected }^{\mathbf{x}}\end{array}$ & $\begin{array}{c}\text { Plots } \\
\text { infected }^{\mathbf{y}}\end{array}$ \\
\hline January & $0.256 \mathrm{abc}^{\mathrm{z}}$ & $0.622 \mathrm{ab}$ \\
February & $0.276 \mathrm{abc}$ & $0.580 \mathrm{ab}$ \\
March & $0.248 \mathrm{ab}$ & $0.500 \mathrm{ab}$ \\
April & $0.250 \mathrm{ab}$ & $0.538 \mathrm{ab}$ \\
May & $0.233 \mathrm{a}$ & $0.512 \mathrm{ab}$ \\
June & $0.348 \mathrm{abc}$ & $0.845 \mathrm{bc}$ \\
July & $0.276 \mathrm{abc}$ & $0.762 \mathrm{ab}$ \\
August & $0.601 \mathrm{c}$ & $0.970 \mathrm{c}$ \\
September & $0.206 \mathrm{ab}$ & $0.845 \mathrm{bc}$ \\
October & $0.442 \mathrm{bc}$ & $0.830 \mathrm{bc}$ \\
November & $0.154 \mathrm{a}$ & $0.470 \mathrm{a}$ \\
December & $0.283 \mathrm{abc}$ & $0.679 \mathrm{ab}$ \\
Mean & 0.294 & 0.670 \\
\hline
\end{tabular}

${ }^{\mathrm{w}}$ Cucumbers were planted in soil collected each month for a period of 24 months from a 'Willamette' red raspberry planting infected with ToRSV.

${ }^{x}$ Proportion of roots infected with ToRSV of all bioassay plants assayed each month. Cucumbers were planted in six subsamples of soil collected each month from 12 field plots, i.e., 72 assay plants were tested for each month in each year. Data were arcsine transformed before ANOVA was performed.

${ }^{y}$ Proportion of plots from which ToRSV was detected in the roots of at least one assay plant, i.e., data represent 12 plots for each month in each year. Data were arcsine transformed before ANOVA was performed.

${ }^{\mathrm{z}}$ Means in each column followed by the same letter do not differ significantly $(P=0.05)$ according to Fisher's LSD tests. 
early fall, coincident with peak adult densities (29). Griffin and Darling (21) similarly observed two population peaks of $X$. americanum on spruce in Wisconsin in late spring to early summer and in the autumn. Population densities were low in summer and winter. These and other studies on maple (15), corn (35), lilac (41), grape (25), and sod (18) differed from our observations over 4 years in the raspberry field. In all 4 years, we observed a single population peak in late fall and winter, with all stages present throughout the year, and females were never greater than $30 \%$ of the population. In contrast to the aforementioned research, soil in raspberry production regions of the PNW rarely freeze in the winter and have very low moisture content in late summer; both conditions can result in high mortality of $X$. americanum $(20,21)$.

Seasonal changes in root growth and root quality can be important for nematodes associated with perennial plants. Xiphinema spp. feed preferentially on the tips of young roots $(10,15)$. Raspberry plants have one or more periods of root growth each year (2). Vrain et al. (51) re- ported that the fine root biomass of red raspberry plants in British Columbia was generally greatest from November through March, with peaks in November to December and March. We observed annual patterns of root growth in our grow-bag experiment, i.e., rapid growth in late summer to fall and a secondary period of growth in the spring. Peak root growth was followed by an increase in population densities of $X$. americanum. High feeding pressure of Xiphinema causes cortical breakdown, leading to thinning and darkening of the root system $(10,15)$, which may limit further population development.

Xiphinema spp. are extremely sensitive to disturbance and physiochemical changes in the soil environment (23). Temperatures recorded in our study were within the range conducive for survival, reproduction, and movement of $X$. americanum $(16,20,28)$. Soil moisture has a large influence on the biology of $X$. americanum. Griffin and Barker (20) observed that $X$. americanum populations decreased under both saturated soil and dry soil conditions. Fluctuating soil moisture also has been reported to be detrimental to $X$. ameri-

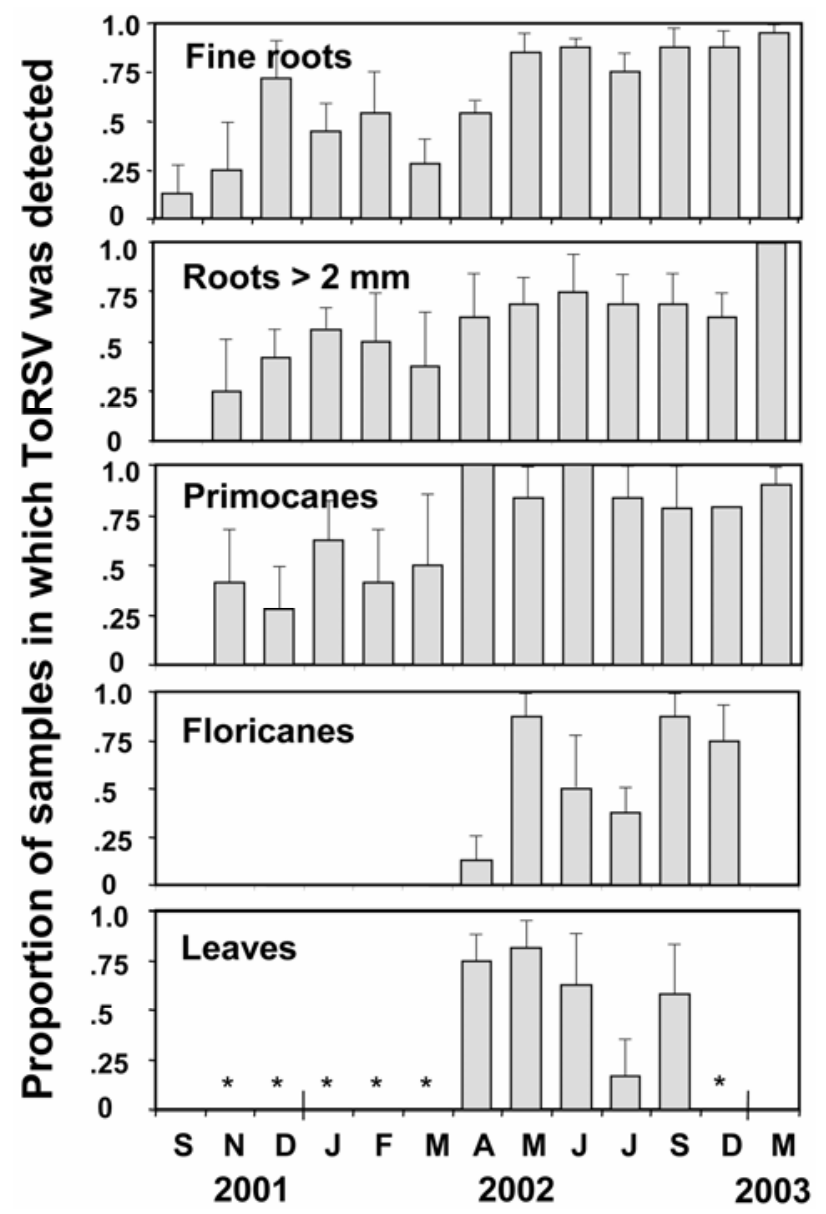

Fig. 4. Infection and systemic spread of Tomato ringspot virus (ToRSV) in 'Meeker' red raspberry during the 2-year period after planting in grow bags filled with field soil infested with viruliferous Xiphinema americanum. Bags containing single plants were buried in a raspberry field in Vancouver, WA. Four plants were destructively harvested at each sampling date. Samples of roots, canes, and leaves from each plant were tested for ToRSV by ELISA. Vertical bars represent standard error. * Leaves were not present from November through March. canum (28) and other Xiphinema spp. $(11,45)$. Van Gundy et al. (49) concluded that soil moisture dictates $\mathrm{O}_{2}$ concentration in the soil, which in turn influences survival of $X$. americanum. Seasonal changes in population densities of $X$. americanumgroup nematodes were coincident with changes in soil moisture content $(18,34,41)$ or irrigation patterns (27). In our study, lower population densities of $X$. americanum were observed in the summer through early fall when soil moisture was low and fluctuated greatly between irrigation cycles.

Based on our research, we propose a developmental pattern for $X$. americanum on red raspberry in the Pacific Northwest as follows: Gravid females are present only in late spring to early summer, which is in agreement with observations of Jaffee et al. (27) and Malek (29) and similar to timing of reproduction in three other Xiphinema species (17). Population densities decline in response to low and fluctuating soil moisture content during the summer $(11,18,21,34,41,45)$. Although gravid females were observed only in the spring, increasing population densities and the greatest percentage of juveniles occurred in the fall, indicating that egg hatch is delayed. This suggests that dormant eggs survive in the soil (29) and hatch when conditions are conducive, i.e., when soil moisture increases in the fall. In addition, hatching of Xiphinema spp. eggs may be stimulated for females that survive dry soil conditions (45). During the early summer, there is little root growth and few young roots due to reduced soil moisture and the allocation of resources to fruit production (2). A flush of new root growth commences after fruiting in midsummer and is followed by increasing nematode population densities when soil moisture increases midfall. All stages overwinter, but the largest proportion of individuals consists of juveniles, reflecting the cohort that developed from eggs hatched the previous fall. The proportion of females in the population increases in early spring as the soil warms to temperatures that are conducive for nematode development (20,28). This pattern was consistent over a 4-year period, although the amplitude of population peaks differed between years as the vigor of the plants declined.

Transmission of nepoviruses by $X$. americanum sensu lato has been reported to be dependent on population density of the vector $(3,5,18,31)$. Although single nematodes can transmit nepoviruses within 1 to $24 \mathrm{~h}$ in controlled experiments (46), it appears that population densities of $X$. americanum in the raspberry field were below a threshold required for consistent infection of cucumber assay plants. We observed a negative relationship between population densities of the vector and the transmission of ToRSV to cucumber in soil assayed from each plot. Seasonal trends 
showed a greater frequency of virus transmission to cucumbers planted in soil collected in summer than in soil collected in winter, when population densities were higher. Because the bioassays are conducted under optimal moisture conditions, seasonal patterns in apparent transmission observed with bioassays probably do not accurately represent actual seasonal patterns of transmission in raspberry fields. Under adverse conditions of low soil moisture in the field during summer, nematode movement, feeding, and potential for virus transmission are likely reduced. The periods of natural transmission most likely will be in the early fall and spring when soil moisture and temperature are optimal for nematode activity.

The seasonal pattern observed in the bioassay may, however, reflect seasonal differences in potential transmission (i.e., virus load per nematode) due to biology of the nematode. Although $X$. americanum is an efficient vector of ToRSV, few virus particles are retained in the lumen of the esophagus, suggesting that the virus is readily released (52). During periods of the years when nematode population densities were the highest and the nematodes most active, the virus may have been readily lost during molting (as indicated by large pro- portion of juveniles) or by purging of the virus while feeding. Under adverse conditions, such as low soil moisture, nematodes may become quiescent and cease feeding $(7,48)$. Quiescent nematodes can retain nepoviruses for long periods and transmit the viruses when conditions become favorable for nematode activity $(4,7,14)$. McGuire (31) reported differential transmission of TRSV by different stages of $X$. americanum, with more consistent transmission by adults and pre-adults than by juveniles. In our study, a greater proportion of adults in the summer and fall, coincided with greater transmission to cucumber plants.

Disease progress of nepoviruses in plantings of perennial crops is very slow and generally limited to adjacent plants $(13,38,54)$. Converse and Stace-Smith (13) observed symptom development of ToRSV in two commercial red raspberry fields in Washington State over 2 years. They reported that the rate of virus spread was $2 \mathrm{~m}$ per year to adjacent plants in the row, but with $2.9 \%$ of new infections in discontinuous new foci. However, $20 \%$ of symptomfree plants located within three plants of a symptomatic plant were positive for ToRSV when assayed by mechanical inoculation to indicator plants. Using
ELISA, we observed a similar, but somewhat slower rate of virus spread of $0.6 \mathrm{~m}$ per year over a 7 -year period. Because the plant spacing was $0.6 \mathrm{~m}$ in the rows, virus spread appeared to be restricted to adjacent plants in the row, without developing secondary foci. The difference in the rate and pattern of virus spread between these studies may be explained by management practices. When the disease focus was located in our study, management practices were modified to restrict nematode-virus spread by limiting soil movement, i.e., perennial grass was established in the alleyways where machines travel and all cultivation was eliminated.

Without movement of nematodeinfested soil from a ToRSV infection focus, the rate of spread of ToRSV will be a function of systemic spread of the virus in the plant and the subsequent transmission of ToRSV to adjacent plants by nematodes. In migration experiments, $X$. americanum moved directionally up to $30 \mathrm{~cm}$ toward host plants in 10 weeks $(3,37)$. In raspberry plantings with dense, perennial root systems, however, Xiphinema spp. need to move little to seek suitable roots to feed on (6). Bergeson et al. (3) concluded that the spread of TRSV between cucumber plants was a function of the roots growing in the

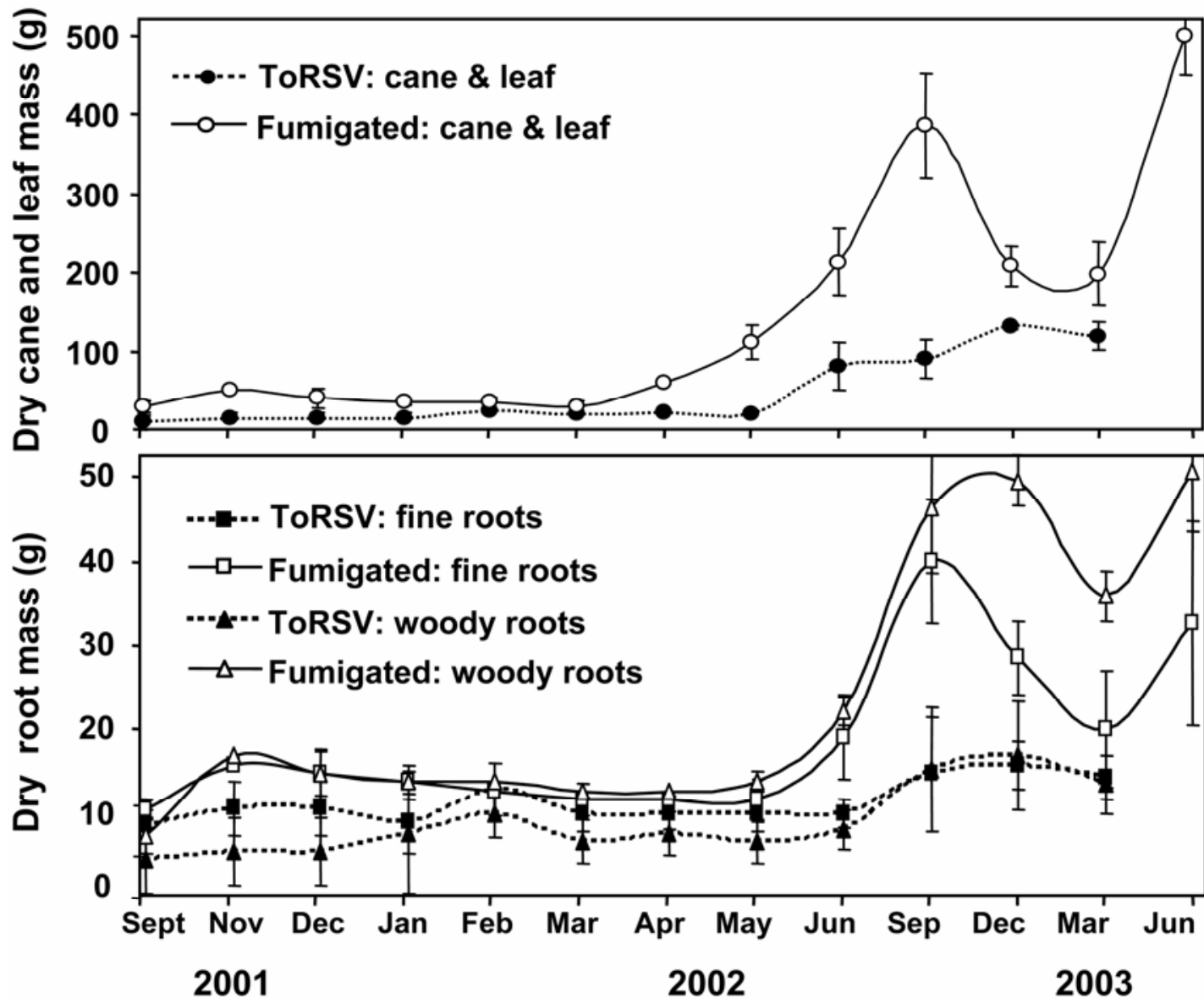

Fig. 5. Growth patterns of 'Meeker' red raspberry plants during the 2-year period after planting in fumigated soil and in soil infested with viruliferous Xiphinema americanum. Four plants grown in grow bags in a raspberry field in Vancouver, WA, were destructively harvested at each sampling date. All fine roots $\leq 2$ mm diameter, woody roots, and the aerial portion of each plant were separated, oven-dried at $70^{\circ} \mathrm{C}$ for $48 \mathrm{~h}$, and weighed. Vertical bars represent standard error. 
vicinity of viruliferous nematodes and not substantial movement of viruliferous nematodes between plants. McNamara (32) also concluded that plant-to-plant spread of Arabis mosaic virus by $X$. diversicaudatum in noncultivated vegetation was a function of systemic spread of virus through the root system, not nematode movement. This is consistent with the natural spread of ToRSV that we observed in the raspberry field. We hypothesize that spread of ToRSV occurs when viruliferous nematodes feed among the distal ends of roots of adjacent plants in the row. Since 1 year was required for red raspberry to become systemically infected by ToRSV, the natural rate of disease spread from a focus in a row should average one plant per year, which agrees with our observations.

There can be differences in the efficiencies with which different virus strains are vectored by $X$. americanum $(7,8,19,26)$. The specificity of retention and transmission of the nepoviruses are dependent on a compatible pairing of virus coat protein and nematode (1). The $99 \%$ homology of coat protein among the raspberry isolates of ToRSV in several regions of the PNW, and rate of disease spread observed in the current and previous study (13), suggest transmission efficiency and disease progress will be similar in raspberry plantings throughout the region. The homology of ToRSV in raspberry fields also suggests that the virus was spread by movement of vegetatively propagated plant materials in the past.

The spread of ToRSV in red raspberry fields is amenable to management. ToRSV may be present only in two to three adjacent symptom-free plants in the row adjacent to symptomatic plants. If a disease focus is detected early, removing plants surrounding the disease focus and treatment of the area with a nematicide or fumigant and reducing or eliminating tillage should minimize further virus spread. By planting perennial grass in the alleyway (36), further movement of soil with machine travel and the establishment of common weedy hosts of ToRSV, such as dandelion $(33,36)$, can be limited.

\section{LITERATURE CITED}

1. Andret-Link, P., Schmitt-Keichinger, C., Demangeat, G., Komar, V., and Fuchs, M. 2004. The specific transmission of Grapevine fanleaf virus by its nematode vector Xiphinema index is solely determined by the viral coat protein. Virology 320:12-22.

2. Atkinson, D. 1973. Seasonal changes in the length of white unsuberized root on raspberry plants grown under irrigated conditions. J. Hortic. Sci. 48:413-419.

3. Bergeson, G. B., Athow, K. L., Laviolette, F. A., and Thomasine, S. M. 1964. Transmission, movement, and vector relationships of tobacco ringspot virus in soybean. Phytopathology 54:723-728.

4. Bitterlin, M. W., and Gonsalves, D. 1987. Spatial distribution of Xiphinema rivesi and persistence of tomato ringspot virus and its vector in soil. Plant Dis. 71:408-411.

5. Bonsi, C., Stouffer, R., and Mountain, W. 1984. Efficiency of transmission of tomato ringspot virus by Xiphinema americanum and Xiphinema rivesi. (Abstr.) Phytopathology 74:626.

6. Brown, D. J. F., Halbrendt, J. M., Jones, A. T., Taylor, C. E., and Lamberti, F. 1994. An appraisal of some aspect of the ecology of nematode vectors of plant viruses. Nematol. Mediterr. 22:253-263.

7. Brown, D. J. F., Halbrendt, J. M., Jones, A. T., Vrain, T. C., and Robbins, R. T. 1994. Transmission of three North American nepoviruses by populations of four distinct species of the Xiphinema americanum group. Phytopathology 84:646-649.

8. Brown, D. J. F., Halbrendt, J. M., Robbins, R. T., and Vrain, T. C. 1993. Transmission of nepoviruses by Xiphinema americanum-group nematodes. J. Nematol. 25:349-354.

9. Brown, D. J. F., Robertson, W. M., and Trudgill, D. L. 1995. Transmission of viruses by plant nematodes. Annu. Rev. Phytopathol. 33:223-249.

10. Cohn, E. 1970. Observation of the feeding and symptomatology of Xiphinema and Longidorus on selected hosts. J. Nematol. 2:167173.

11. Cohn, E., and Mordechai, M. 1970. The influence of some environmental and cultural conditions on rearing populations of Xiphinema and Longidorus. Nematologica 16:8593.

12. Converse, R. H., and Martin, R. R. 1990. ELISA for plant viruses. Pages 179-196 in: Serological Methods for Detection and Identification of Viral and Bacterial Plant Pathogens. R. Hamptom, E. Ball, and S. DeBoer, eds. American Phytopathological Society, St. Paul, MN.

13. Converse, R. H., and Stace-Smith, R. 1971. Rate of spread and effect of tomato ringspot virus on red raspberry in the field. Phytopathology 61:1104-1106.

14. Demangeat, G., Voisin, R., Minot, J.-C., Bosselut, N., Fuchs, M., and Esmenjaud, D. 2005. Survival of Xiphinema index in vineyard soil and retention of Grapevine fanleaf virus over extended time in the absence of host plants. Phytopathology 95:1151-1156.

15. Di Sanzo, C. P., and Rohde, R. A. 1969. Xiphinema americanum associated with maple decline in Massachusetts. Phytopathology 59:279-284.

16. Douthit, L. B., and McGuire, J. M. 1975. Some effects of temperature on Xiphinema americanum and infection of cucumber by tobacco ringspot virus. Phytopathology 65:134138.

17. Flegg, J. J. M. 1968. Life-cycle studies of some Xiphinema and Longidorus species in southeastern England. Nematologica 14:197210.

18. Flores, H., and Chapman, R. A. 1968. Population development of Xiphinema americanum in relation to its role as a vector of tobacco ringspot virus. Phytopathology 58:814-817.

19. Greisbach, J. A., and Maggenti, A. R. 1989. Vector capability of Xiphinema americanum sensu lato in California. J. Nematol. 21:517523.

20. Griffin, G. D., and Barker, K. R. 1966. Effects of soil temperature and moisture on the survival and activity of Xiphinema americanum. Proc. Helminthol. Soc. Wash. 33:126-130.

21. Griffin, G. D., and Darling, H. M. 1964. An ecological study of Xiphinema americanum Cobb in an ornamental spruce nursery. Nematologica 10:471-479.

22. Halbrendt, J. M., and Brown, D. J. F. 1992. Morphometric evidence for three juvenile stages in some species of Xiphinema americanum sensu lato. J. Nematol. 24:305-309.
23. Halbrendt, J. M., and Brown, D. J. F. 1993. Aspects of biology and development of Xiphinema americanum and related species. $\mathrm{J}$ Nematol. 25:355-360.

24. Halbrendt, J. M., and Brown, D. J. F. 1994. Inter- and intraspecific variation in wild-type and single female-derived populations of Xiphinema americanum-group nematodes. J. Nematol. 26:212-221.

25. Harris, A. R. 1980. Population studies of Xiphinema pachtaicum and X. americanum in a vineyard in north-east Victoria. Res. 52 Project Series. Mildura Hortic. Res. Stn. Dep. Agric., Victoria No. 75, p. 8.

26. Hoy, J. W., Mircetich, S. M., and Lownbery, B. F. 1984. Differential transmission of prunus ringspot virus strains by Xiphinema californicum. Phytopathology 74:332-335.

27. Jaffee, B. A., Harrison, M. B., Shaffer, R. L., and Strang, M. B. 1987. Seasonal population fluctuation of Xiphinema americanum and $X$. rivesi in New York and Pennsylvania orchards. J. Nematol. 19:369-378.

28. Lownsbery, B. F., and Maggenti, A. R. 1963. Some effects of soil temperature and soil moisture on population levels of Xiphinema americanum. Phytopathology 53:667-668.

29. Malek, R. B. 1969. Population fluctuation and observations of the life cycle of Xiphinema americanum associated with cottonwood (Populus deltoides) in South Dakota. Proc. Helminthol. Soc. Wash. 36:270-274.

30. McElroy, F. D. 1992. A plant health care program for brambles in the Pacific Northwest. J. Nematol. 24:457-462.

31. McGuire, J. M. 1964. Efficiency of Xiphinema americanum as a vector of tobacco ringspot virus. Phytopathology 54:799-801.

32. McNamara, D. G. 1980. The spread of Arabis mosaic virus through non-cultivated vegetation. Plant Pathol. 29:173-176.

33. Miller, P. M. 1980. Reproduction and survival of Xiphinema americanum on selected woody plants, crops, and weeds. Plant Dis. 64:174175.

34. Norton, D. C. 1963. Population fluctuation of Xiphinema americanum in Iowa. Phytopathology 53:66-68.

35. Norton, D. C., and Edwards, J. 1988. Age structure and community diversity of nematodes associated with maize in Iowa sandy soils. J. Nematol. 20:340-350.

36. Pinkerton, J. N., and Martin, R. R. 2006. Management of Tomato ringspot virus in red raspberry with crop rotation. Int. J. Fruit Sci. 5:5567.

37. Ponchillia, P. E. 1972. Xiphinema americanum as affected by soil organic matter and porosity. J. Nematol. 4:189-193.

38. Ramsdell, D. C., and Myers, R. L. 1987. Epidemiology of peach rosette mosaic virus in a Concord grape vineyard. Phytopathology 69:447-450.

39. Robbins, R. T. 1993. Distribution of Xiphinema americanum and related species in North America. J. Nematol. 25:344-348.

40. Scheer, W. P. A., and Garren, R. 1981. Commercial red raspberry production. Washington State University, Oregon State University, and University of Idaho. PNW Bull. 176. Washington State University, Pullman.

41. Schmitt, D. P. 1973. Soil property influences on Xiphinema americanum populations as related to maturity of loess-derived soils. J. Nematol. 5:234-240.

42. Siddiqi, M. R. 1973. Xiphinema americanum. Description of plant-parasitic nematodes, Set 2, No. 29. Commonwealth Institute of Helminthology, St. Albans, England.

43. Spiegel, S., and Martin, R. R. 1993. Improved detection of potato leafroll virus in dormant potato tubers and micro-tubers by polymerase chain reaction and ELISA. Ann. Appl. Biol. 122:493-500. 
44. Stace-Smith, R., and Converse, R. H. 1987. Tomato ringspot virus in Rubus. Pages 223227 in: Virus Disease of Small Fruits. R. H. Converse, ed. U.S. Dep. Agric. Agric. Handb. No. 631. Washington, DC.

45. Sultan, S. A., and Ferris, H. 1991. The effect of soil moisture and soil particle size on the survival and population increase of Xiphinema index. Rev. Nématol. 14:345-351.

46. Téliz, D., Grogan, R. G., and Lownsbery, B. F. 1966. Transmission of tomato ringspot, peach yellow bud, and grape yellow vein viruses by Xiphinmea americanum. Phytopathology 56:658-663.

47. Thompson, J. D., Higgins, D. G., and Gibson, T. J. 1994. CLUSTALW: Improving the sensitivity of progressive multiple sequence alignment through sequence weighting, position- specific gap penalties and weight matrix choice. Nucleic Acids Res 22:4673-4680.

48. Trudgill, D. L., Brown, D. J. F., and McNamara, D. G. 1983. Methods and criteria for assessing the transmission of plant viruses by Longidorid nematodes. Rev. Nématol. 6:133141.

49. Van Gundy, S. D., Stoltz, L. H., Szuszkiewicz, T. E., and Rackham, R. L. 1962. Influence of oxygen supply on survival of plant parasitic nematodes in soil. Phytopathology 52:628632.

50. Vrain, T. C. 1993. Restriction fragment length polymorphism separates species of the Xiphinema americanum group. J. Nematol. 25:806808.

51. Vrain, T. C., Forge, T. A., and DeYoung, R. 1997. Population dynamics of Pratylenchus penetrans parasitizing raspberrry. Fundamental Appl. Nematol. 20:29-36.

52. Wang, S., Gergerich, R. C., Wickizer, S. L., and Kim, K. S. 2002. Localization of transmissible and nontransmissible viruses in the vector nematode Xiphinema americanum. Phytopathology 92:646-653.

53. Wang, A., and Sanfaçon, H. 2000. Proteolytic processing at a novel cleavage site in the $\mathrm{N}$ terminal region of the tomato ringspot nepovirus RNA-1-encoded polyprotein in vitro. J. Gen. Virol. 81:2771-2781.

54. Welland, C. N., and Perez-Comacho, F. 2004. Comparison of the logistic and Gompertz equations to describe plant disease progress of grapevine fanleaf virus (GLFV) in 'Condado de Haelva' (Spain) zone. Acta Hortic. 652:305308 . 